\title{
Peroxide oxidation of lipids and antioxidant protection of an organism of cows during dry period at impact of antibiotic of prolonged action
}

\author{
S. Ohrym, \\ Candidate of Agricultural Sciences \\ Ternopil Experimental Station of the Institute of Veterinary Medicine of NAAS
}

The purpose. To study effect of antibiotic of prolonged action Oksiprol on processes of peroxide oxidation of lipids and activity of ferments of antioxidant systems of blood of cows during dry period. Methods. Biochemical, photometric, statistical. To cows of experimental group 30 day prior to calving intramuscularly inducted a specimen Oksiprol in dose of $1 \mathrm{~cm} 3$ for $10 \mathrm{~kg}$ of mass of a body. Results. After application of Oksiprol during dry period the content of diene conjugates in blood serum drops for $28,47 \%(P<=0,01)$, of malonic dial - for $12,5 \%(P<=0,05)$, while catalase activity increases for $36,47 \%$ $(P<=0,01)$, and density of hepatocuprein - for 30,55\% $(P<=0,01)$ in comparison with the beginning of experiment, on the background of uncertain fluctuation of the content of these indexes in blood of cows of control group. Conclusions. Application of Oksiprol in dry period makes active enzymatic link of antioxidant protection of an organism, slows down activity of processes of peroxide oxidation of lipids, which prevent development of morbid conditions. With the purpose of prophylactics of development of morbid conditions at cows it is recommended

Key words: cows, dry period, antibiotics, lipid peroxidation, antioxidant system of blood

Formulation of the problem. The main tasks of dairy farming are stabilization and increase livestock of cows, the increase in of gross of production volumes and improve product quality. Compelling reasons of deterrence the pace of industry development in contemporary conditions is the reduction of of an organism natural resistance of the cows that results in metabolic disease, activating conditionally pathogenic microflora and of development of inflammatory processes [1].

Analysis of recent research and publications. In the period of dead wood is important to minimize any of stress effect, guarantee balanced nutrition and optimum conditions of the animals. On the average $40-50 \%$ of cows in the herd may be subclinical the bacterial infection in the udder. In this case milk remain a visually unchanged, but the microbiological analysis gives tested positive for pathogens of mastitis. The main purpose period of dead wood is the maximum recovery of ability of cells the mammary gland cows to the formation of milk, reducing the level is present and prevent the emergence of new intramammary of infection $[2,3,4,5,6]$.

To reduce the risk of complications and the treatment of cows use a broad spectrum antibioticswhich act throughout the 60-day period of deadwood [7, 8, 9, 10, 11, 12, 13, 14].

In development of inflammation is also important process enhancing free radical oxidation [15]. As an alternative of free radical processes in organism exists antioxidant protection presented system antioxidative enzymes and of natural antioxidants [16].

The materials and methods. Experiments conducted in LLC «Agroprodservice-Invest» Ternopil region cows Ukrainian black and white dairy cattle. Biochemical studies conducted in the laboratory of veterinary obstetrics and gynecology Ternopil Experimental Station of the Institute of Veterinary Medicine of NAAS.

At the preparatory stage been formed experimental and control groups of animals $(n=10)$. In the experimental group of cows 30 days before calving introduced by intramuscular injection medication «Oksyprol» a dose of $1,0 \mathrm{~cm}^{3}$ per $10 \mathrm{~kg}$ body weight (equivalent to $20 \mathrm{mg}$ oxytetracycline for $1 \mathrm{~kg}$ of body weight)._A control served as cows, which did not use the drug. 
«Oksyprol» - based a drug oxytetracycline dihydrate - broad spectrum of action antibiotic that belongs to the group of tetracyclines. Excipients drug «Oksyprol»: Magnesium (II) oxide, depyrogenized water, other components that stabilize the drug and its prolonged effect. It is important to note that when administered in the indicated dose therapeutic concentration of active substance in the body is stored cows for 4-days. Producer of the drug «Oksyprol» - SPC LLC «Brovafarma» c. Brovary, Ukraine.

Before and after drug administration and control cows in the experimental group have taken blood for biochemical research. The content of diene conjugates studied extraction heptane, isopropyl alcohol, malonic dyaldehidu by color reaction with tiobarbiturovoyu acid, catalase activity by color reaction with ammonium molybdate content ceruloplasmin the reaction of enzymatic oxidation of muriatic parafenilendyaminu [17].

Statistical processing the results carried out using standard computer programs. The difference between the two values was considered probable by ${ }^{*}-p<0,05 ;{ }^{* *}-p<0,01 ;{ }^{* *}-p<0,001$ [18].

Results and discussion. The data regarding the impact the drug "Oksyprol» content of diene conjugates, malonic dyaldehidu, ceruloplasmin and catalase activity in blood of cows during the deadwood is presented in table 1.

The data presented in table 1 shows that cows after application of the drug «Oksyprol» deadwood during content diene conjugates and malonic dyaldehidu in the blood decreases, respectively, 28,47\% $(p \leq 0,01)$ and $12,50 \%(p \leq 0,05)$ compared with their level before the introduction. Whereas in the blood of cows of control group was observed improbable reducing the content of indicated indicators.

Table 1. The content of the products of lipid peroxidation, antioxidant of an organism parameters cows before and after the drug «Oksyprol» during deadwood, $n=10, M \pm m$

\begin{tabular}{|c|c|c|c|c|}
\hline \multirow[t]{3}{*}{ Indicators } & \multicolumn{4}{|l|}{ Groups of cows } \\
\hline & \multicolumn{2}{|l|}{ «Oksyprol» } & \multicolumn{2}{|l|}{ control } \\
\hline & $\begin{array}{ll}\text { Beginning } & \text { of } \\
\text { experiment }\end{array}$ & $\begin{array}{l}\text { the end of the } \\
\text { experiment }\end{array}$ & $\begin{array}{l}\text { Beginning of } \\
\text { experiment }\end{array}$ & $\begin{array}{l}\text { the end of the } \\
\text { experiment }\end{array}$ \\
\hline $\begin{array}{l}\text { Diene conjugates, } \\
\mathrm{mkmol} / \mathrm{l}\end{array}$ & $57,82 \pm 3,94$ & $41,36 \pm 2,41^{* *}$ & $57,98 \pm 3,31$ & $55,45 \pm 3,80$ \\
\hline Malonic dyaldehid, mkmol/l & $5,68 \pm 2,27$ & $4,97 \pm 2,47^{*}$ & $5,76 \pm 2,41$ & $5,50 \pm 2,94$ \\
\hline $\begin{array}{l}\text { The activity of catalase, } \\
\text { mkat /l }\end{array}$ & $4,36 \pm 1,20$ & $5,95 \pm 1,59^{* *}$ & $4,32 \pm 1,74$ & $4,69 \pm 1,36$ \\
\hline $\begin{array}{l}\text { Ceruloplasmine, } \\
\mathrm{mkmol} / \mathrm{I}\end{array}$ & $0,72 \pm 0,01$ & $0,94 \pm 0,02^{* *}$ & $0,68 \pm 0,01$ & $0,73 \pm 0,01$ \\
\hline
\end{tabular}

Note: ${ }^{*}-p \leq 0,05 ;{ }^{* *}-p \leq 0,01$ compared with indicators to a introduction of the drug

The function of antioxidant system aimed at the the disposal of toxic products of free radical oxidation and maintaining bioradykalnoyi balance. Inhibition of free radical oxidation processes dependent on the activity antioxidative enzimov systems in which the significant role played by catalase and ceruloplasmine. Catalase $\left(\mathrm{H}_{2} \mathrm{O}_{2}, \mathrm{H}_{2} \mathrm{O}_{2}\right.$ - oxidoreductases, $\mathrm{CF}$ 1.11.1.6) is an intracellular antioxidant that prevents accumulation of hydrogen of peroxide formed at of anion dismutation peroxidic, of hydrogen peroxide metabolizuyuchy on water and molecular Oxygen.

After entering drug "Oksyprol» during the dead wood (Table 1) is set to enhance of catalase activity of blood serum of cows the experimental group at $36,47 \%(p \leq 0,01)$ compared to a indicators of the drug, the improbable increasing content of this indicator in the blood cows of the control group.

Protective function of the associated with of ceruloplasmin property of of inhibiting active oxygen metabolites and lipids in autookysnennya prevent of damaged membranes of cells. It was established that concentration of of ceruloplasmin in blood serum of cows the experimental group after the drug «Oksyprol» dead wood in the period increased by $30.55 \%(r \leq 0,01)$ compared with the beginning of the 
experiment, against the backdrop of improbable modifying the content of this indicator in the blood of cows of the control group (Table 1).

\section{Summary}

1. Application of the drug cows «Oksyprol» in the dry period activates the enzymatic link of antioxidant defense of the body, inhibits lipid peroxidation processes, that prevent the development of pathological conditions.

2. In order to prevent the development of pathological conditions in cows is recommended to enter 30 days before the of calving intramuscularly drug «Oksyprol» in a dose of $1,0 \mathrm{~cm}^{3}$ per $10 \mathrm{~kg}$ body weight.

\section{Bibliography}

1. Yablonsky, V.A., \& Lyubetsky, V.J., \& Yukhymchuk, S.K., \& et al. (2000). Vidtvoryuval'na zdatnist' koriv $\mathrm{v}$ umovakh kryzovoho stanu hospodarstva [The reproductive ability of cows in conditions of crisis state farming]. Naukovyy visnyk Natsional'noho ahrarnoho universytetu. Problemy fiziolohiyi i patolohiyi vidtvorennya tvaryn - Scientific Bulletin of National Agrarian University. Problems of physiology and pathology of animal reproduction 22. Kyiv, 75-77 [in Ukrainian].

2. Bradley, A. J., \& Breen, J.E., \& Payne B., \& Green, M.J. (2011). A comparison of broad-spectrum and narrow-spectrum dry cow therapy used alone and in combination with a teat sealant. Journal of Dairy Science, Vol. 94, Issue 2, 692-704 [in English].

3. Collier, R.J., \& Annen-Dawson, E.L., \& Pezeshki, A. (2012). Effects of continuous lactation and short dry periods on mammary function and animal health. Animal, Mar;6(3):403-14 [in English].

4. Cameron, M., \& McKenna, S.L., \& MacDonald, K.A., \& Dohoo, I.R., \& Roy, J.P., \& Keefe, G.P. (2014). Evaluation of selective dry cow treatment following on-farm culture: risk of postcalving intramammary infection and clinical mastitis in the subsequent lactation. Journal of Dairy Science, Jan;97(1):270-84 [in English].

5. Cameron, M., \& Keefe, G.P., \& Roy, J.P., \& Stryhn, H., \& Dohoo, I.R., \& McKenna, S.L. (2015). Evaluation of selective dry cow treatment following on-farm culture: Milk yield and somatic cell count in the subsequent lactation. Journal of Dairy Science, Apr;98(4):2427-36 [in English].

6. Cameron, M., \& Keefe, G.P., \& Roy, J.P., \& Dohoo, I.R., \& MacDonald, K.A, \& McKenna, S.L. (2013). Evaluation of a 3M Petrifilm on-farm culture system for the detection of intramammary infection at the end of lactation. Prev. Vet. Med., Aug 1;111(1-2):1-9 [in English].

7. Klenowa, I.F., \& Maltsev, K.Jl., \& Yaremenko, N.Y., \& Arkhipov, I.A. (2004). Veterynarnыe preparatu $v$ Rossyy: spravochnyk $v$ 2-kh tomakh [Veterinary preparations in Russia: a handbook in 2 volumes]. Moscow: Selhozizdat, Part 1 [in Russian].

8. Grechuhin, A.N. (2006). Novoe sredstvo pry bakteryal'nom symptomokomplekse [A new remedy for bacterial symptom complex]. Veterynaryya - Veterinary medicine;8,6-8 [in Russian].

9. Bradley, A.J., \& Breen, J.E., \& Payne, B., \& Williams, P., \& Green, M.J. (2010). The use of a cephalonium containing dry cow therapy and an internal teat sealant, both alone and in combination. Journal of Dairy Science;93:1566-1577 [in English].

10. Bradley, A.J., \& Green, M.J. (2001). An investigation of the impact of intramammary antibiotic dry cow therapy on clinical coliform mastitis. Journal of Dairy Science;84:1632-1639 [in English].

11. Bachman, K.C., \& Schairer M.L. (2003). Invited review: bovine studies on optimal lengths of dry periods. Journal of Dairy Science, Vol. 86, No. 10:3027-3037 [in English].

12. Pezeshki, A., \& Capuco, A.V., \& De Spiegeleer B., \& Peelman L., \& Stevens M., \& Collier R.J., \& Burvenich C. (2010). An integrated view on how the management of the dry period length of lactating cows could affect mammary biology and defence. J. Anim. Physiol. Anim. Nutr. (Berl), Oct;94(5):e7-30 [in English].

13. Scherpenzeel, C.G., \& den Uijl, I.E., \& van Schaik, G., \& Olde Riekerink, R.G., \& Keurentjes, J.M., \& Lam, T.J. (2014). Evaluation of the use of dry cow antibiotics in low somatic cell count cows. Journal of Dairy Science, Jun;97(6):3606-14 [in English]. 
14. Petzer I.M., \& Lourens D.C., \& Watermeyer J.C., \& Rautenbach G.H., \& Thompson P. (2009). Intramammary infection rate during the dry period in cows that received blanket dry cow therapy: efficacy of 6 different dry-cow intra-mammary antimicrobial products. J. South. African. Vet. Assoc.;1: 23-30 [in English].

15. Vladimirov, Yu.A., \& Archakov, A.I. (1972). Perekysnoe okyslenye lypydov v byolohycheskykh membranakh [Lipid peroxidation in biological membranes]. Moscow: Nauka [in Russian].

16. Lankin, V.Z., \& Tihaze, A.K., \& Belenkov, Y.M. (2001). Svobodnoradykalnыe protsessы v norme y pry patolohycheskykh sostoianyiakh: Posobye dlia vrachei [Free-radical processes in normal and pathological conditions: A Handbook for Physicians]. Moscow: Science [in Russian].

17. Shcherban, N.G., \& Gorbach, T.V., \& Guseva N.R. (2004). Laboratornыe metodyky dlya yzuchenyya sostoyanyya antyoksydantnoy systemb orhanyzma y urovnya perekysnoho okyslenyya lypydov: Metodycheskye rekomendatsyy dlya doktorantov, aspyrantov, mahystrov, yspolnyteley NYR. [Laboratory techniques for the study of the state of antioxidant system and lipid peroxidation: Guidelines for doctoral students, graduate students, masters, artists research]. Kharkov: HGMU [in Russian].

18. Lakyn, G.F. (1990). Byometryya: Uchebnoe posobye dlya byolohycheskykh spetsyal'nostey vuzov. [Biometrics: A manual for biological specialties universities] Moscow: Higher School [in Russian]. 